\title{
Experimental Analysis of Behavior and Damage of Sandwich Composite Materials in Three-Point Bending. Part 2. Fatigue Test Results and Damage Mechanisms
}

\author{
A. Bezazi, ${ }^{\text {a,b }}$ A. El Mahi, ${ }^{\text {' J.-M. Berthelot, }}{ }^{d}$ and B. Bezzazi ${ }^{\mathrm{e}}$ \\ a Laboratoire de Mécanique et Structure (LMS), Université de Guelma, Algeria \\ ${ }^{\mathrm{b}}$ Department of Aerospace Engineering, University of Bristol, Bristol, UK \\ ' Université du Maine, Le Mans, France \\ d ISMANS, Institute for Advanced Materials and Mechanics, Le Mans, France \\ e Laboratoire des Matériaux Minéraux et Composite (LMMC), Université de Boumerdes, \\ Boumerdes, Algeria
}

УДК 539.4

\section{Экспериментальные исследования прочности и повреждения многослойных композитных материалов при испытаниях на трехточечный изгиб. Сообение 2. Результаты усталостных испытаний и механизмы повреждения}

\author{
А. Безази а, \\ a Университет г. Гуэльма, Алжир \\ ${ }^{\sigma}$ Университет г. Бристоль, Великобритания \\ ${ }^{\text {в }}$ Университет г. Ле Манс, Франция \\ г Институт перспективных материалов и механики, г. Ле Манс, Франция \\ д Университет г. Бумэрди, Алжир
}

\begin{abstract}
Выполнень экспериментальные исследования изменения жесткости и механизмов повреждения при усталостных испьтаниях многослойных композитних пластин с наполнителем из пеновинилопласта. Многослойные композитные пластины с перекрестныли слоями из стекловолокна и эпоксидной смоль, изготовленнье методом вакуумной отливки, подвергали нагруженио трехточечныл изгибол. Исследовали два варианта пластин с однотипньли наполнителяли из пеновинилопласта различной плотности. Рассмотрено влияние плотности и толиины внутреннего слоя наполнителя на поведение и повреждение композита. $C$ использованием двух различньх моделей и критерия циклической долговечности построень кривье усталости и выполнен их сравнительньй анализ с имеющимися литературньми данньми. Показано, что композит SD 2 с наполнителем большей плотности обладает более вьсокими характеристикали статической прочности и устойчивости, а также усталостной прочности по сравненио с колпозитом SD 1 с наполнителем меньшей плотности.
\end{abstract}

Ключевые слова: пеновинилопласт, многослойные композитные пластины, наполнитель, трехточечный изгиб, механизм разрушения, критерий циклической долговечности. 
Introduction. This paper is the continuation of a previous paper [1], which concerned the behavior and damage propagation under static loading of three sandwich composite materials and their components [skins and polyvinyl chloride (PVC) cores]. The static tests permit to have the characteristics necessary for performing fatigue tests, results of which are presented in this paper.

Materials and Experimental Procedure. Two types of sandwich materials with different kinds of cores were investigated. The skins were cross-ply laminates $\left(0_{2} / 90_{2}\right)_{s}$ consisting of unidirectional glass fibre fabric with a surface density of $300 \mathrm{~g} / \mathrm{m}^{2}$ and epoxy resin SR 1500/SD whose principal characteristics are given in [1]. Two similar types of PVC foam of different density were used. A Herex C70 55 and a C70 75 foams were expanded PVC provided by the Airex company and marketed by SICOMIN company in panels of 15 and $25 \mathrm{~mm}$ thickness. The two foams used were different in density: $60 \mathrm{~kg} / \mathrm{m}^{3}$ for the Herex C70 55 and $80 \mathrm{~kg} / \mathrm{m}^{3}$ for the Herex C70 75. The diameter of the pores varied between 620 and $880 \mu \mathrm{m}$ for the C70 55 and between 280 and $500 \mu \mathrm{m}$ for the C70 75 .

The sandwich manufacturing was carried out at the laboratory using a vacuum bag moulding technique. The manufacture of the sandwich, the skins and the joining of the core, was carried out at the same time with the laying up of the skin plies and then by interposing the core and the second skin. The sandwich was impregnated at room temperature, and then was vacuumed at a pressure of $30 \mathrm{kPa}$ for 10 hours inside the mould. Prior to tests, the plates were left at room temperature for 2 to 3 weeks in order to provide a complete polymerization of the epoxy resin.

The specimens (foams, skins, and sandwich) were cut out using a diamond saw from plates of $300 \times 300 \mathrm{~mm}$ according to ASTM C393-00 standard. Sandwich SD 1 and SD 2 have the same core thickness of $15 \mathrm{~mm}$; they are differentiated by the foam core density. The same foam (C70 75) core is used for SD 2 and SD 3; the only difference lay in the thicknesses of the core which were respectively 15 and $25 \mathrm{~mm}$.

Testing of the specimens was performed, where the applied load was monitored with a $5 \mathrm{kN}$ load cell, the displacement by a LVDT sensor, and the deformation using an extensometer. The supports were of cylindrical shape of $10 \mathrm{~mm}$ diameter for the two lower supports and $15 \mathrm{~mm}$ for the central support. A minimum of five tests was carried out for each type of specimen, the loading rates in the static tests being $5 \mathrm{~mm} / \mathrm{min}$ for the foam core and the sandwiches, and $2 \mathrm{~mm} / \mathrm{min}$ for the skins.

Fatigue tests were carried out in three-point bending using a universal hydraulic monotonic testing machine (INSTRON model 8516 of capacity $\pm 100 \mathrm{kN}$ ) whose control and data acquisition were performed by a computer. The displacement control with a sinusoidal wave form of a frequency of $5 \mathrm{~Hz}$ has been provided. The mean displacement $\left(d_{\text {mean }}\right)$ was maintained constant and equal to $50 \%$ of ultimate failure displacement at static test $\left(d_{r}\right)$. The ratio of the distance between the supports to the thickness of the specimen $l / h$ is 15 .

Fatigue tests included several levels of loading $r_{d}\left(r_{d}=d_{\max } / d_{r}\right)$, which represent the ratio of maximum displacement to ultimate failure displacement at static test varying from 0.95 to 0.55 . 
Results of the Fatigue Tests. The analysis of stiffness degradation constitutes one of the methods most widely used to follow the progression of the damage by fatigue of the composites. During these tests, the evolution of the maximum loading $F$ according to the number of cycles $N$ has been recorded. The maximum loading $F$ was normalized to that obtained at the first cycle $F_{0}$.

The results obtained show that the stiffness degradation until specimens' failure preceded in three phases (Fig. 1): cycles;

i) initially, a sharp reduction of the stiffness $\left(F / F_{0}\right)$ appeared at the first

ii) the reduction becomes rather slow in the second phase, corresponding to the near total consumption of the fatigue life of the specimens;

iii) finally in the third (very short) phase the loss of rigidity accelerated rapidly until the specimen failure.

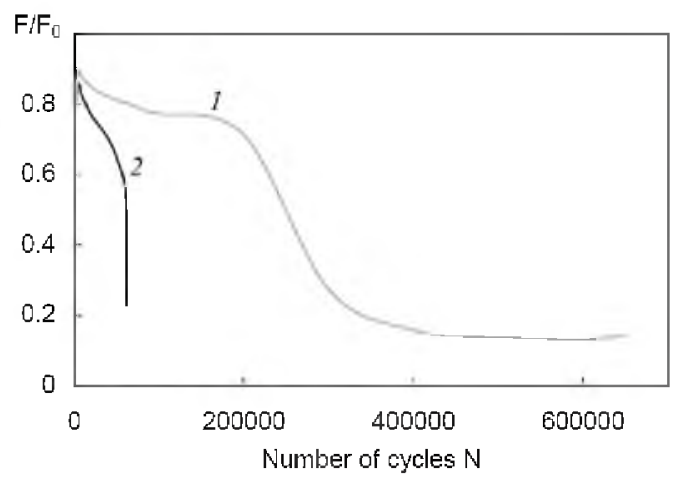

Fig. 1. Stiffness degradation $F / F_{0}$ versus number of cycles of the sandwich SD $1(1)$ and SD 2 (2) for the loading level $r_{d}=0.7$.

This behavior was common for all investigated sandwich specimens. It has also been noticed that the stiffness degradation $\left(F / F_{0}\right)$ of the sandwich specimen SD 1 having the less dense foam core was faster than that of sandwich specimen SD 2.

Figures 2-4 represent the evolution of $F / F_{0}$ versus the number of cycles $N$ for SD 1, SD 2, and SD 3, respectively, for various levels of loading $r_{d}$. The analysis of these results shows that the behavior until failure, under fatigue tests, proceeded in three phases and depended on the level of loading and the type of foam core. For significant levels of loading $r_{d}$, total failure was obtained at the end of only a few hundreds of cycles, whereas for low values of $r_{d}$ failure was only partial even for up to $10^{6}$ cycles.

Noteworthy is that, in the case of SD 2 and SD 3, a steady state is formed after the specimen rupture for certain high levels of loading (Figs. 3 and 4). This behavior, which was not observed for SD 1, seems to be related to the rigidity of the foam (C70 75) which affects the fracture mechanisms.

To compare the behavior of the sandwich specimens experimentally, we have investigated the stiffness degradation according to the number of cycles with several levels of loading (Figs. 2-4). However, in the case of the comparison of the behavior of SD 1 and SD 2 and for visualization reasons, only two loading levels $r_{d}=0.60$ and 0.75 have been reported (Fig. 5). 


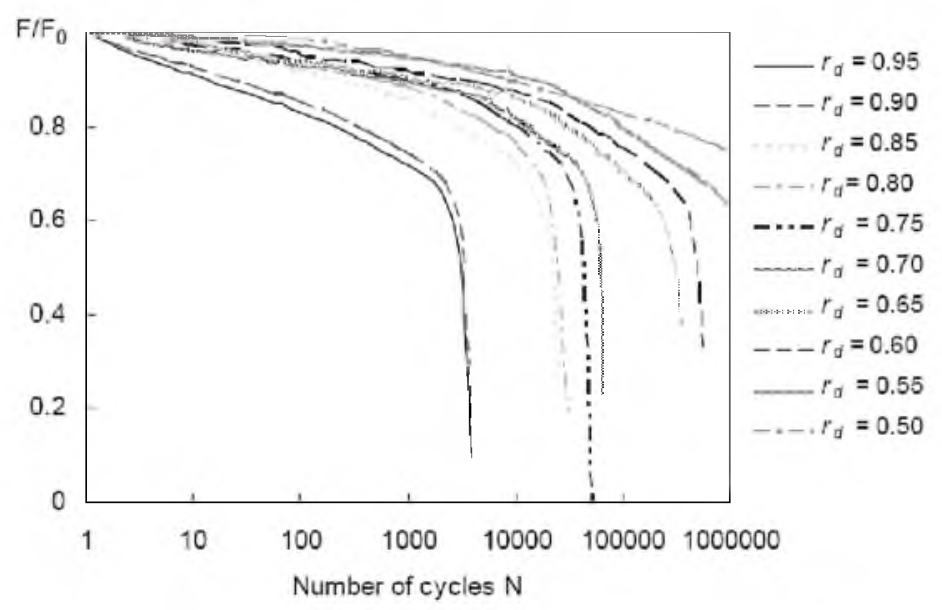

Fig. 2. Stiffness degradation $F / F_{0}$ versus number of cycles of the sandwich SD 1 for various loading levels $r_{d}$.

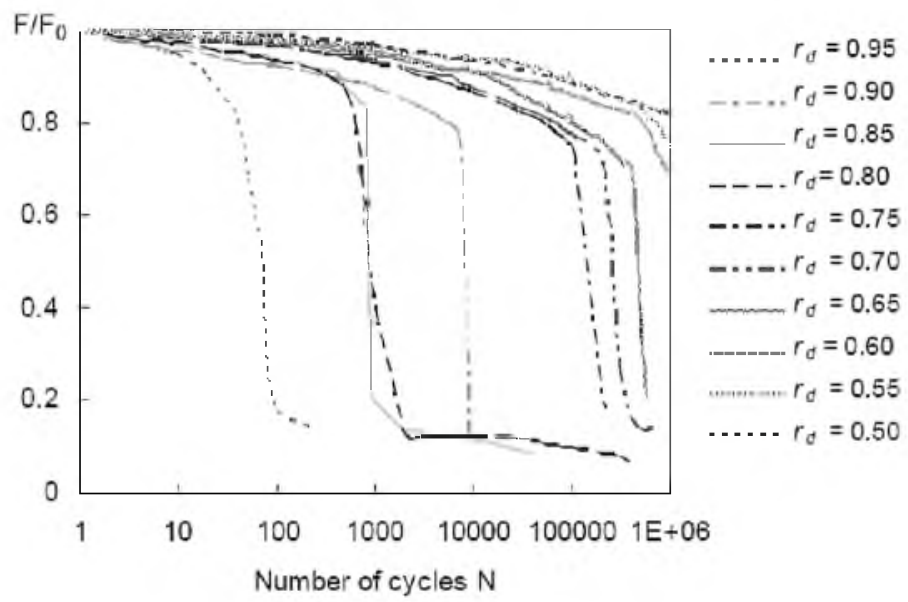

Fig. 3. Stiffness degradation $F / F_{0}$ versus number of cycles of the sandwich SD 2 for various loading levels $r_{d}$.

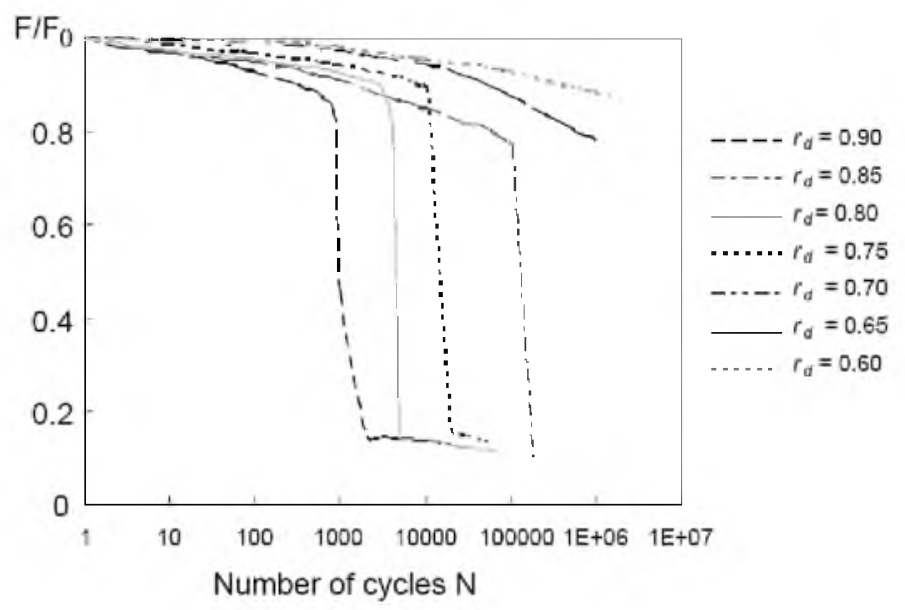

Fig. 4. Stiffness degradation $F / F_{0}$ versus number of cycles of the sandwich SD 3 for various loading levels $r_{j}$. 


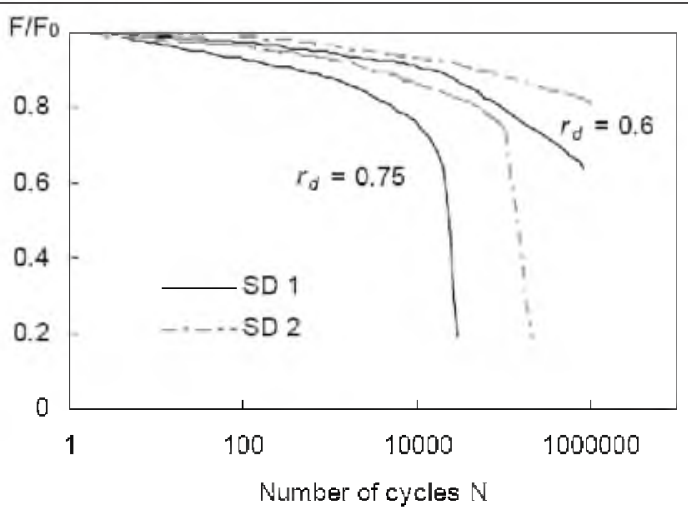

Fig. 5. Foam density influence on the behavior of stiffness degradation $F / F_{0}$ versus number of cycles.

For the same level of loading, the degradation rates in both sandwich specimens are similar in the first few cycles of fatigue. However, for a larger number of cycles the degradation rate of SD 1 was higher than that of SD 2 . Therefore, for a given level of loading, the stiffness degradation curves of SD 1 were located at the lower part of those of SD 2. Consequently, SD 2 resisted better in fatigue than SD 1.

On the other hand, a comparative study of SD 2 and SD 3 for two levels of loading $r_{d}(0.60$ and 0.80$)$ is presented in Fig. 6. For low levels of loading $\left(r_{d} \leq 0.6\right)$ failure was only partial, and the total failure was not reached even when the number of cycles was greater than $10^{6}$. For loading levels $r_{d} \geq 0.6$, the final failure occurred following a number of cycles in the range 100 to several 1000 cycles. The stiffness degradation as well as failure was more apparent for SD 2 than for SD 3 (Fig. 6).

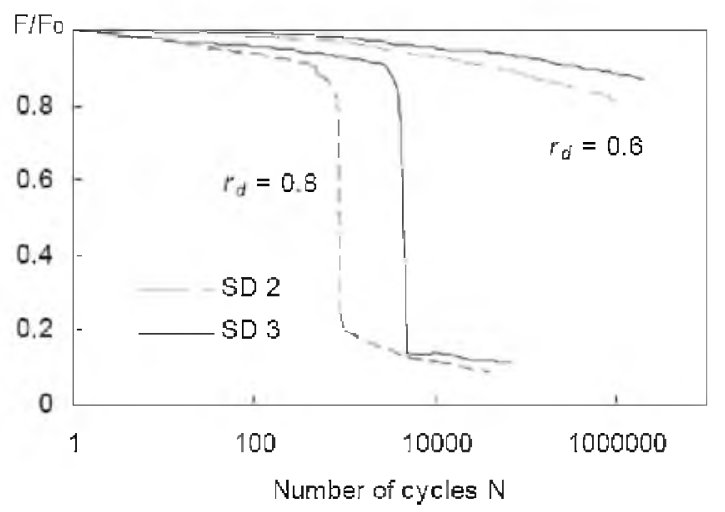

Fig. 6. Foam thickness influence on the behavior of stiffness degradation $F / F_{0}$ versus number of cycles.

Changeover of Damage Mechanisms in Fatigue Process. Fatigue damage propagation of SD 1 and SD 2 was analyzed. The damage in fatigue of the sandwich specimens was different from that which was observed in the case of a static loading. It was found to be dependant on the type of foam core and the level of loading. 
Sandwich Specimens SD 1. The specimens were tested in fatigue at various levels of loading $r_{d}$. It was observed that before the final failure, the specimen undergoes three distinct stages of damage:

- the first stage: crack initiation in the upper part of the foam core under compression just below the loading support at a distance 2 to $3 \mathrm{~mm}$ from the interface between the top skin and core. The latter crack growth (Fig. 7a) evolves at lower rate along to the length direction of the specimen. This stage occurs for most of the fatigue life ( 80 to $90 \%$ );

- the second stage: occurrence of a new mode of failure through an action of core shearing which developed at a higher crack growth rate compared to stage 1 until the interface with the lower skin was reached (Fig. 7b);

- the third stage: delamination with the interface between the core and the lower skin along the length of the specimen at a high crack growth rate (Fig. 7c, d).
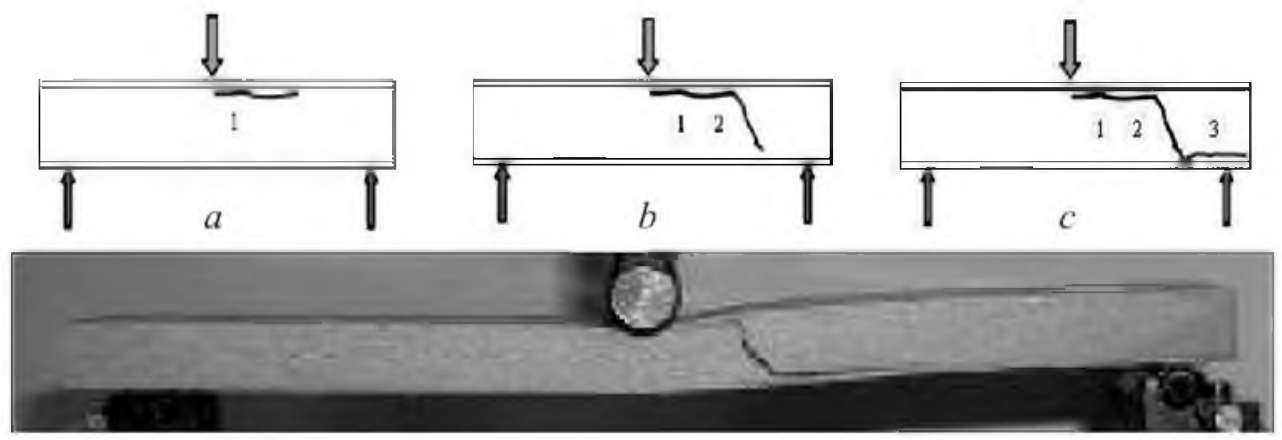

$d$

Fig. 7. Fracture topography after fatigue tests of sandwich SD 1 [(a) stage $1,(b)$ stage $2,(c)$ stage 3 . and $(d)$ photo of the damaged specimen].

These results are in good agreement with those of Kulkarni et al. [2] obtained by using sandwich panels made of glass fibre laminate skins and a low density PVC foam core in three-point bending. The thicknesses of the skin, the core and the sandwich, in [2], are 2.28, 12.7, and $17.26 \mathrm{~mm}$, respectively, the width is $63.5 \mathrm{~mm}$, the length between supports is $228.6 \mathrm{~mm}$, and the overall length $305 \mathrm{~mm}$.

After presenting different damage mechanisms, we then analyzed the influence of the loading level on the evolution of the damage. As shown in Fig. 8a, b, it was found that the three-stage the damage propagation discussed previously, is only apparent when the loading level $r_{d}$ is greater or equal to 0.65 . However, significant crack size and severe damage was noticed at higher loading levels as shown in Fig. 8a. For lower loading levels $\left(r_{d}<0.65\right)$ final failure was not reached even after $10^{6}$ cycles, the crack propagation was limited to stage 1 only (Fig. 8c).

Sandwich Specimens SD 2. The behavior of this sandwich was somewhat different. For loading levels $r_{d} \leq 0.75$, the same three stages seen previously in the case of sandwich SD 1 (Fig. 9a) were observed. However, for $r_{d}>0.75$ the damage propagates only in two stages: initially formation of an indentation crack on the foam under the skin directly below the upper roller at a distance of 1 to $2 \mathrm{~mm}$ from the interface (i.e., where the matrix penetration in the foam ends), followed by rupture of the higher skin in compression (Fig. 9b). In addition the effect of cycling of the specimen after the appearance of the higher skin rupture generated 


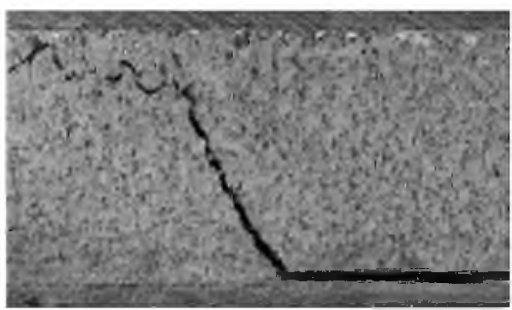

$a$

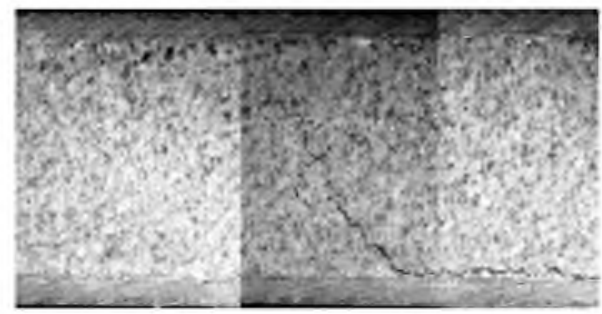

$b$

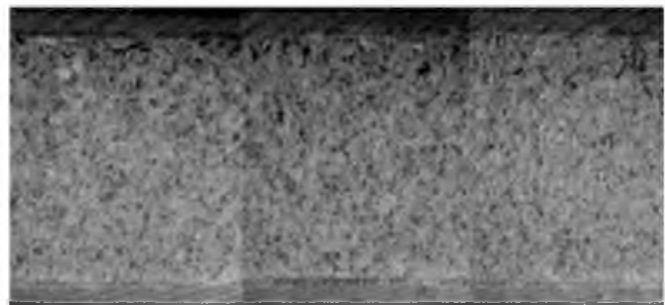

Fig. 8. Fracture topographies of the sandwich SD 1 specimens damaged by fatigue for different loading levels $r_{d}:(a) r_{d}=0.9 ;(b) r_{d}=0.7 ;(c) r_{d}=0.55$.

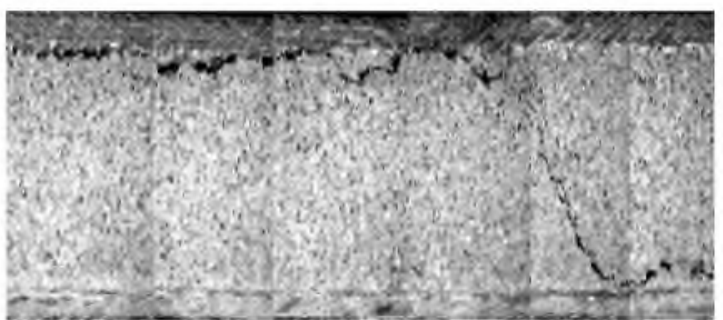

$a$
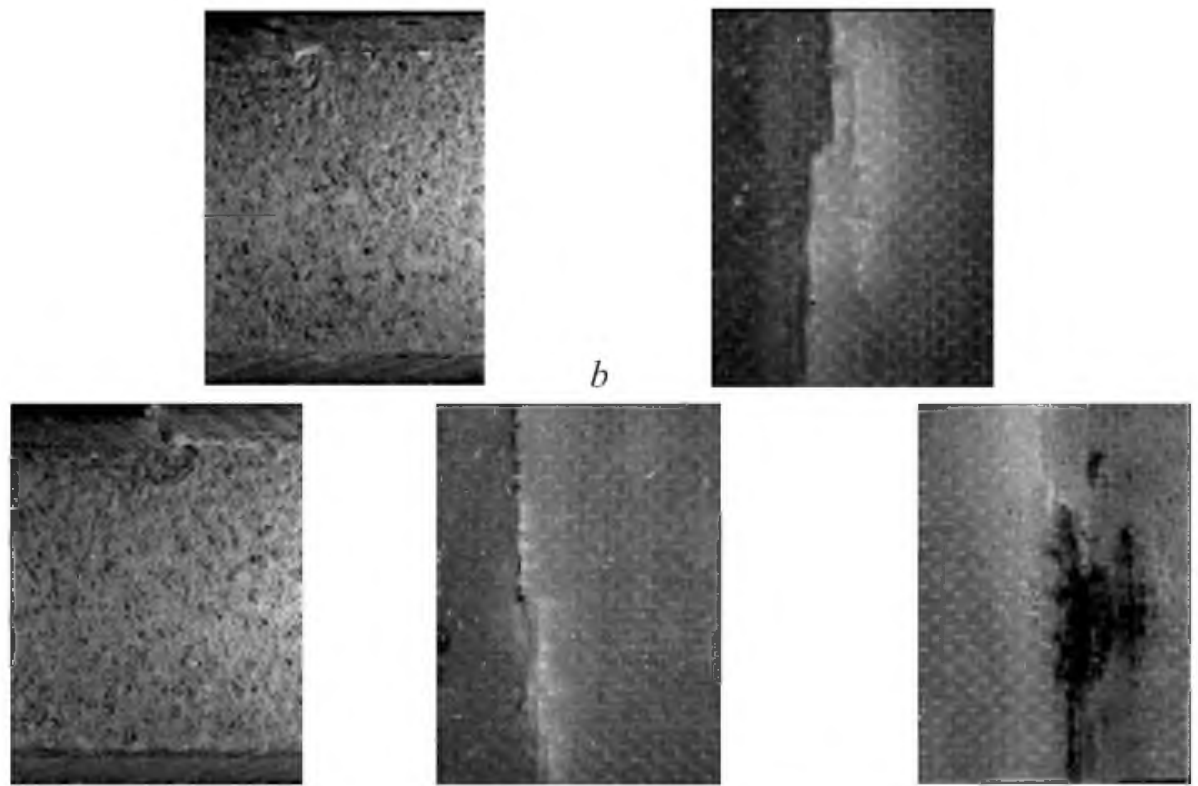

$c$

Fig. 9. Fracture topographies of the sandwich SD 2 specimens damaged by fatigue for different loading levels $r_{d}:(a) r_{d}=0.725 ;(b) r_{d}=0.9 ;(c) r_{d}=0.8$. 
heating due to friction of the fibres which then led to microburns of the matrix under the central support (Fig. 9c).

Wöhler's Curves ( $S-N$ Curves). In the case of displacement control bending fatigue, no sudden and catastrophic failure of the specimens was observed. The definition of the fatigue life was then based on conventional failure criterion defined for a given percentage of stiffness degradation. In order to determine the performance of composite materials in fatigue, various damage criteria $\left(N_{s}, N_{3}\right.$, $N_{5}, N_{10}$, and $N_{R}$ ) are considered in the literature from the curves giving the stiffness degradation as a function of the number of cycles. The most severe criterion is that characterizing the material by the value $N_{s}$, which corresponds to the number of cycles at the end of the linear domain. The criteria $N_{3}, N_{5}$, and $N_{10}$ correspond to falls of 3,5 , and $10 \%$ of the load (or displacement) in relation to the initial load (or displacement), respectively. The criterion $N_{R}$ corresponds to the number of cycles at the final failure of the specimen. Finally, the performances in fatigue can be characterized by the number of cycles necessary to cause failure of the material when this number of cycles is reached. In our investigation, we have chosen the criterion $N_{10}$, which is the most frequently used in the literature [3-13]. Beyond 10\%, many damage mechanisms are involved and their description becomes more difficult, for example, for higher damage rates, the effect of local heating in the specimen cannot be neglected [7].

The Wöhler's curves obtained for composites with organic matrix are very often described by a linear relation introduced by Mandell [14] in the case of uniaxial load control fatigue,

$$
\sigma=U T S-B \log N_{r},
$$

where UTS and $B$ are two constants which depend on the material and the conditions of tests respectively. This formula was adopted by Fiore [7] and Salvia et al. [5] for displacement control flexural tests,

$$
\varepsilon=A-B \log N_{10} .
$$

Several studies made it possible to show that this type of relation can be applied to a number of glass fibre composites $[4,15,16]$, with carbon reinforcement $[17,18]$, and also on hybrid materials [20].

Sims and Gladman [15] introduced a relation slightly different from the relation (1)

$$
\sigma=U T S-B \log 2 N_{r}
$$

The parameter UTS represents the value of stress for which the material has half cycle fatigue life, which corresponds only to the loading phase of the fatigue loading cycle. Fiore [7] also adopts the same point of view by introducing the concept of $D A F$ (Permissible Deformation in Flexural), defined by

$$
\varepsilon=D A F-B \log 2 N_{10}
$$

Wöhler's curves descriptions, given by the Eqs. (1)-(4) comprise two components: the first comes from the monotonous behavior (modulated by the effect of the 
loading speed) and is represented by the DAF or UTS parameters, the second, more intrinsically related to the phenomenon of fatigue, is represented by $B$, the slope of the fitting of the experimental data. Indeed, the DAF and UTS parameters are independent from the fatigue concept, as they are values obtained for a half cycle of loading, therefore not taking into account all parameters (for example the effect of the cycles accumulation). The slope $B$ relates the dependence of the fatigue life of the material to the level of applied loading. Its value represents the endurance of the material.

To take into account these two contributions and in order to compare the fatigue resistance of various materials, Caprino and Giorleo [21] use normalized curves

$$
\frac{\sigma}{\sigma_{t}}=1-B \log N_{10}
$$

Here we have applied the following two approaches. Firstly, we used a relation equivalent to (2) to compare our results with those of the literature and, secondly, a relation equivalent to (5) as follows:

$$
\begin{gathered}
A m p_{\max }=A-B \log N_{10}, \\
r_{d}=1-K \log N_{10} .
\end{gathered}
$$

Equation (7) makes it possible to highlight the influence of the type and thicknesses of foam core using only one parameter $K$ which is the slope of the right-hand side of endurance corresponding to the rate of fall of the acceptable maximum loading expressed in \% decade by cycle.

The experimental results of Wöhler's curves as well as curve fitting by the relation (6) are represented in Figs. 10 and 11, in order to compare our results with those of the bibliography $[7,8,12,18]$. These figures represent the maximum amplitude versus the number of cycles of SD 1, SD 2, and SD 3.

In Table 1, we compare our results with the ratios $A / B$ given by several authors: Tambora [6], Fiore [7], Vautier [8], Roudet [9], Madell [14], Fournier [16], and Clark [22] for various materials in flexural tests.

Noteworthy is that the result of ratio $A / B$ for $\mathrm{SD} 1$ is the same one as that which was obtained in the work of Clark [22] for glass/epoxy composites sandwich panels using PVC foam C70 130. The results of SD 2 and SD 3 remain in the same order of magnitude as those obtained in the work of Vauthier [8], Roudet [9], and Fournier [16].

Figure 12 represents the Wöhler's curves of the investigated sandwich specimens (SD 1 and SD 2), using the Eq. (7); these curves are already presented in Fig. 4 using Eq. (6). This describes the evolution of the maximum loading normalized to the static failure load as a function of the fatigue life using criterion $N_{10}$ for $d_{m o y}=0.5 d_{\text {rup }}$ drup maintained constant and for the ratio $l / h=15$.

Even though sandwich panels are of a heterogeneous nature, the results obtained show less pronounce scatter of the fatigue life data. For low numbers of cycles where the level of loading was close to that of the static failure, tending towards unity independently of the sandwich type as illustrated in Figs. 12 and 13. 
$\mathrm{T}$ a b 1 e 1

Ratio $A / B$ for Different Materials Subjected to Flexural Tests

\begin{tabular}{|c|c|c|c|c|c|c|c|c|c|}
\hline & \multicolumn{3}{|c|}{ Present work } & [CLA-97] & [FIO-88] & [FOU-92] & [VAU-96] & [ROU-98] & [TAM-96] \\
\hline & SD 1 & SD 2 & SD 3 & Sandwich & \multicolumn{5}{|c|}{ Laminates } \\
\hline Material & \multicolumn{3}{|c|}{ Glass/epoxy (sd) } & \multicolumn{5}{|c|}{ Glass/epoxy } & $\begin{array}{c}\text { Carbon/ } \\
\text { epoxy }\end{array}$ \\
\hline $\begin{array}{l}\text { Loading } \\
\text { type }\end{array}$ & \multicolumn{9}{|c|}{ Flexural } \\
\hline $\begin{array}{l}\text { Ratio } \\
A / B\end{array}$ & 10 & 14 & 16.7 & 10 & 10 & $11.6-18.3$ & $10-16$ & 14 & 12 \\
\hline
\end{tabular}

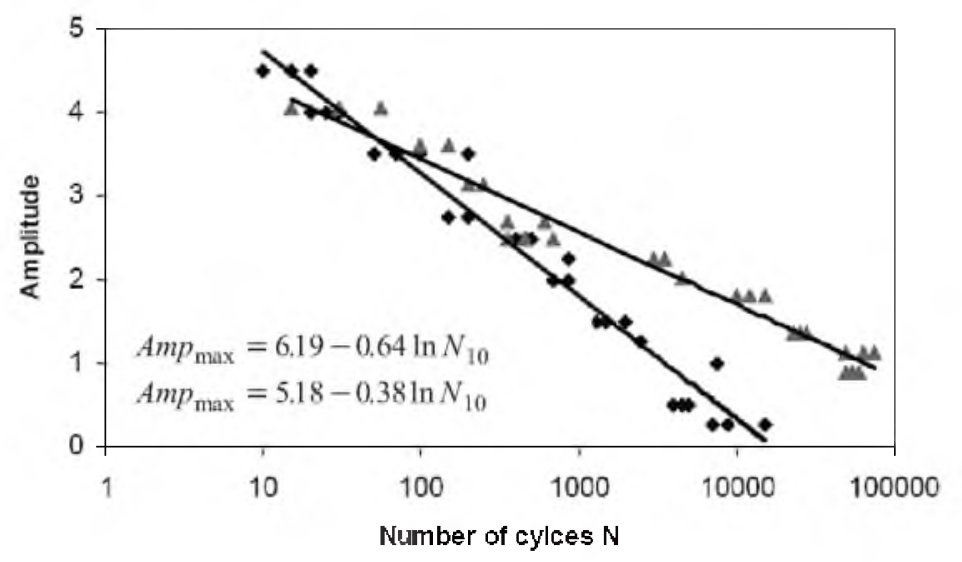

Fig. 10. Wöhler's curves fitted by the relation (6) for sandwiches SD $1(\bullet)$ and SD $2(\boldsymbol{A})$.

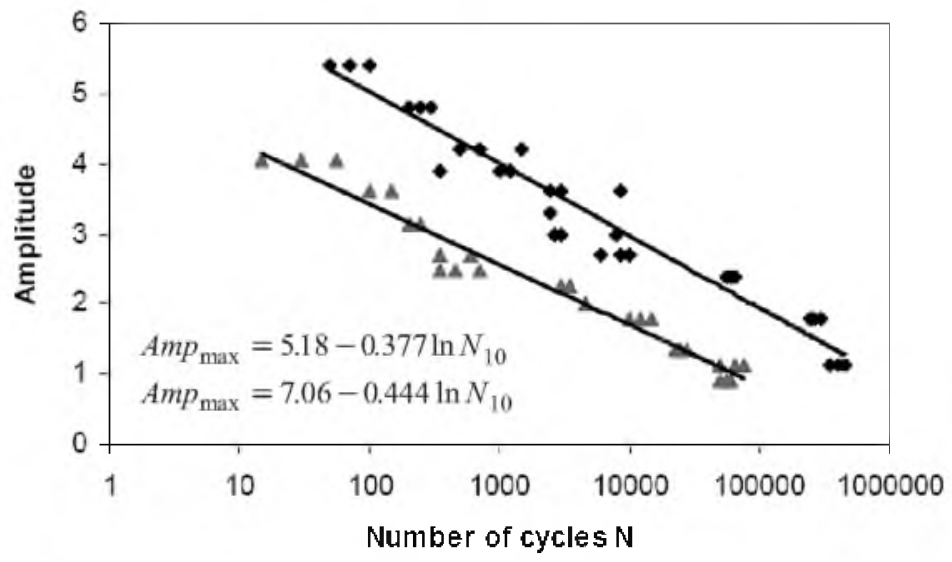

Fig. 11. Wöhler's curves fitted by the relation (6) sandwiches SD 2 (A) and SD 3

In this case, the total failure was obtained after the first few cycles. However, for low loading levels the failure was only partial even for high numbers of cycles going up to $10^{6}$.

The analysis of the results obtained (Fig. 12) highlights the influence of the type of core over the fatigue life of the investigated sandwich specimens. SD 2 having the densest core had a higher resistance to fatigue. Whereas, the Wöhler's 


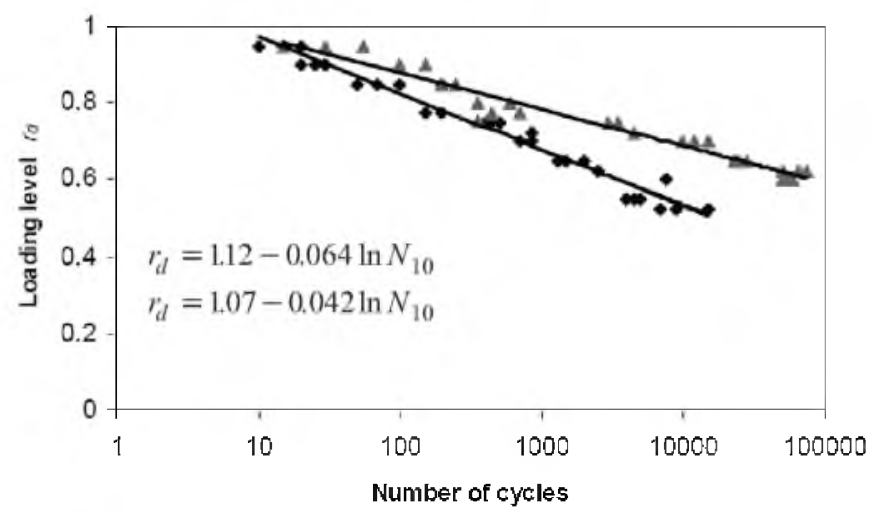

Fig. 12. Wöhler's curves fitted by the relation (7) sandwiches SD 1 and SD 2.

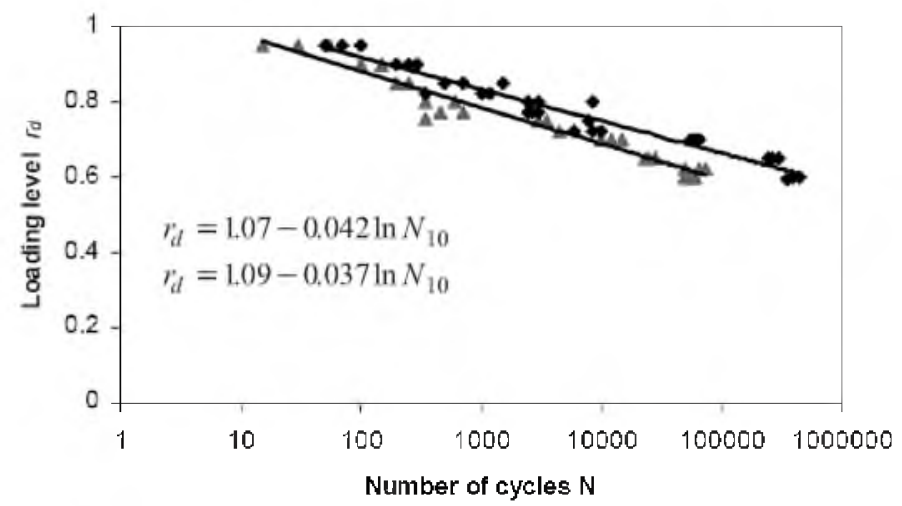

Fig. 13. Wöhler's curves fitted by the relation (7) sandwiches SD 2 and SD 3.

curve of SD 1 was lower then that of SD 2 indicating that the value of $K$ in the case of SD 2 was smaller than that for SD 1. In addition to that, it can be noticed that the evolution of the stiffness degradation $\left(F / F_{0}\right)$ crosses the $Y$-axis at a value of around 1, which corresponds to the static failure load.

Figure 13 represents Wöhler's curves for SD 2 and SD 3 already presented on Fig. 5 obtained by using Eq. (6). The same form of representation was used as in the preceding case [Eq. (7)]. These curves highlighted the influence of the thickness of the core and the criterion of life $N_{10}$ on the damage degradation rate.

For a better illustration of the influence of the core thickness over the fatigue life of the sandwich specimen, we used the same description as that used previously. It is clear that the value of $K$ increased when the core thickness decreased. Therefore, for the same level of loading, the fatigue life increases when the core thickness increases, consequently SD 3 had a higher fatigue resistance then that of SD 2.

Conclusions. Typical damage accumulation curves in the form of stiffness degradation were observed on the sandwich specimens that were subjected to fatigue loading tests. As generally agreed by researchers in the literature, three phases of fatigue life were derived from the stiffness degradation curves. These phases are found to be dependant on the loading level $r_{d}$ as well as the type of core. 
Moreover, this investigation has revealed that sandwich specimen SD 2, having the densest core, was more rigid, had the largest static load at rupture and was more resistant to fatigue than sandwich SD 1. The effect of core thickness increase, from 15 to $25 \mathrm{~mm}$, led to an increase of $37 \%$ of the static load at failure and improved the fatigue resistance resulting in a specimen with a better fatigue strength. Moreover, fatigue damage of sandwich specimens was different from that which was observed in the case of a static loading. It was found to be dependant on the type of foam core and the loading level.

\section{Резгме}

Проведено експериментальні дослідження зміни жорсткості та механізмів пошкодження при випробуваннях на втому багатошарових композитних пластин iз наповнювачем із піновінілопласта. Багатошарові композитні пластини 3 перехресними шарами зі скловолокна та епоксидної смоли, виготовлені методом вакуумного відливу, піддавали навантаженню триточковим згином. Досліджували два варіанта пластин 3 однотипними наповнювачами 3 піновінілопласта різної щільності. Розглянуто вплив щільності і товщини внутрішнього шару наповнювача на поведінку та пошкодження композита. Із використанням двох різних моделей та критерію циклічної довговічності побудовано криві втомленості і проведено їх порівняльний аналіз із відомими літературними даними. Показано, що композит SD 2 з наповнювачем великої щільності має більш високі характеристики статичної міцності і стійкості та утомної міцності порівняно 3 композитом SD 1 із наповнювачем меншої шільності.

1. A. Bezazi, A. El Mahi, J.-M. Berthelot, and B. Bezzazi, "Experimental analysis of behavior and damage of sandwich composite materials in threepoint bending. Part 1. Static tests and stiffness degradation at failure studies," Strength Mater., 39, No. 2, 170-177 (2007).

2. N. Kulkarni, H. Mahfuz, S. Jeelani, and L. A. Carlsson, "Fatigue crack growth and life prediction of foam core sandwich composites under flexural loading," Compos. Struct., 59, 499-505 (2003).

3. A. El Mahi, M. Khawar Farooq, S. Sahraoui, and A. Bezazi, "Modelling the flexural behavior of sandwich composite materials under cyclic fatigue," Mater. Design, 25, 199-208 (2004).

4. V. M. Harik, J. R. Klinger, and T. A. Bogetti, "Low-cycle fatigue of unidirectional composites: Bilinear $S-N$ curves," Int. J. Fatigue, 24, 455-462 (2002).

5. M. Salvia, L. Fiore, P. Fournier, and L. Vincent, "Flexural fatigue behavior of UDGFRP experimental approach," Int. J. Fatigue, 9, No. 3, 253-262 (1997).

6. S. Tamboura, H. Sidhom, et H. P. Lieurade, "Matériau composite à fibre de carbone et matrice époxyde: étude du mécanisme d'endommagement," Matériau et Techniques, No. 3-4, 15-20 (1996).

7. L. Fiore, Contribution à l'Étude du Comportement en Fatigue de Matériaux Composite à Renfort Verre Unidirectionnel, Thèse de l'Ecole Centrale de Lyon (1988). 
8. E. Vauthier, Durabilité et Vieillissement Hygrothermique de Composites Verre/Epoxyde Soumis à des Sollicitations de Fatigue, Thèse de l'Ecole Centrale de Lyon (1996).

9. F. Roudet, Comportement en Flexion Trois Points avec Cisaillement Prépondérant de Composites Verre/Époxyde Unidirectionnels: sous Chargement Monotones et Cyclique, Thèse de Doctorat de 1'Université des Sciences et Technologie de Lile (1998).

10. A. R. Bezazi, A. El Mahi, J.-M. Berthelot, and B. Bezzazi, "Flexural fatigue behavior of cross-ply laminates: An experimental approach," Strength Mater., 35, No. 2, 149-161 (2003).

11. A. R. Bezazi, A. El Mahi, J.-M. Berthelot, and A. Kondratas, "Investigation of cross-ply laminates behaviour in three point bending tests. Pt. II: Cyclic fatigue tests," Mater. Sci., 9, No. 1, 128-133 (2003).

12. A. R. Bezazi, A. El Mahi, J.-M. Berthelot, and B. Bezzazi, "Influence of reinforcement in cross-ply laminates in flexural testing," in: New Trends in Fatigue and Fracture (Congr., Apr. 8-9, 2002).

13. A. R. Bezazi, A. El Mahi, J.-M. Berthelot, and B. Bezzazi, "Analyse du comportement et de l'endommagement des matériaux composites sandwiches en flexion 3-points," 16ème Congrès Français de Mécanique (Nice, 1-5 Septembre 2003).

14. J. F. Mandell, "Fatigue behavior of fibre resin composites," in: P. G. Pritchard (Ed.), Developments in Reinforced Plastics, Applied Science Publ., London; New York (1982), pp. 67-107.

15. G. D. Sims and D. G. Gladman, "A framework for specifying the fatigue performance of glass fibre reinforced plastics," in: NPL Report DMA (a) 59 (1982), pp. 1-24.

16. P. Fournier, Comportement sous Sollicitation Cyclique des Composites Unidirectionnels Verre/Époxy. Cas des Résines à Ténacité Améliorée, Thèse de 1'Ecole Centrale de Lyon (1992).

17. P. T. Curtis, "Tensile fatigue mechanisms in unidirectional polymer matrix composite materials," Int. J. Fatigue, 13, No. 5, 377-382 (1991).

18. B. Haris, H. Reiter, T. Adam, et al., "Fatigue behavior of carbon fibre reinforced plastics," Composites, 21, No. 3 (1990).

19. L. Lorenzo and H. T. Hahn, "Fatigue failure mechanisms in unidirectional composites," in: H. T. Hahn, (Ed.), Composite Materials: Fatigue, ASTM STP 907, Philadelphia (1986), pp. 210-232.

20. H. Harel, J. Aronhime, K. Schulte, et al., "Rate dependent fatigue of aramidfibre/carbon-fibre hybrids," J. Mater. Sci., 25, 1313-1317 (1990).

21. G. Caprino and G. Giorleo, "Fatigue lifetime of glass fibre/epoxy composites," J. Compos., Part A: Appl. Sci. Manufact., 30, 299-304 (1999).

22. S. D. Clark, Long Term Behavior of FRP Structural Foam Cored Sandwich Beams, Ph.D Thesis, University of Southampton, UK (1997). 